\title{
Towards an Entrepreneurial University Model: Evidence from the Palestine Polytechnic University
}

Ibrahim M Awad ( $\square$ iawad@staff.alquds.edu )

Al Quds University Faculty of Administration and Economic Science https://orcid.org/0000-0001-75495261

Meera Kh. Salaimeh

Al-Quds University

\section{Research}

Keywords: Entrepreneurship, Entrepreneurial University, Entrepreneurial education, PPU, Innovation, Funding

Posted Date: July 22nd, 2021

DOI: https://doi.org/10.21203/rs.3.rs-724756/v1

License: (c) (i) This work is licensed under a Creative Commons Attribution 4.0 International License. Read Full License 


\section{Abstract}

This study aims to introduce a proposed model for transforming the Palestine Polytechnic University (PPU) towards an entrepreneurial university. Toward that end, a quantitative approach using statistical techniques of t-test, ANOVA, Kruskal-Wallis test, and Pairwise comparisons supported by explanatory and qualitative discussions were utilized. The main findings show that the applicability of entrepreneurship at PPU was relatively fair for the aspects of the compatibility of curricula with the labor market needs, community relations and partnerships, academic exchange, entrepreneurship culture, entrepreneurial education, and university internationalization. Entrepreneurship as a policy objective was moderately acceptable for university policies and regulations, scientific research and innovation, and university leadership, but the university environment was less than moderate. The findings also show that the university leadership acknowledges the importance of achieving entrepreneurship, while they pay insufficient attention to the academic exchange. Offering other supportive funding resources can accelerate entrepreneurship. Given that, this study is likely to provide a proposed model to transform PPU into an entrepreneurial university and effectively achieve the University's pioneering vision that contributes to the University's development and presents this model to the decision-makers.

\section{Introduction}

In light of Palestinian universities' financial pressures to become self-sufficient, the speed of the growing economy and its requirements may negatively affect Palestinian universities' missions and visions. Thus, a need was required to propose a new model for transforming the traditional Palestinian universities into an entrepreneurial university since it is the key to access the knowledge economy and its role in solving the financial aspect and enhancing the development of society economically (Etzkowitz, 2006). The Palestine Polytechnic University (PPU) is considered one of the Palestinian universities striving to be an entrepreneurial university in its educational and administrative aspects. It faces several crises and obstacles, including financial support, due to the occupation policies based on withholding support and its restrictions on the government and the higher education sector. It is a Palestinian university that has a good reputation in entrepreneurship. (Palestine Polytechnic University site, 2017). From this standpoint, this study is prepared to address this issue because of its importance and value for developing an entrepreneurial university by proposing a model for transforming the University into an entrepreneurial university, as a case study for Palestine Polytechnic University.

Accordingly, the study's research gap is determined by the absence of a specific and precise term of entrepreneurship at both the academic and administrative levels. In particular, there is a misunderstanding of the characteristics and pillars of an entrepreneurial university's conceptualization. On the other hand, there is no unified model for the entrepreneurial concept, characteristics, and items between universities. (Interview with the senior university administration, 2019). Further, such a proposed model can be adopted as a transformative model for other Palestinian universities. Therefore, this study formulated three specific questions for proposed an entrepreneurial model to the PPU as shown below: 
- What is the reality of entrepreneurship at the PPU from the viewpoint of senior and middle management?

- What are the requirements to transform the PPU towards an entrepreneurial university from the senior and middle management perspective?

- Are there any potential differences between the study population responses on their assessment of the entrepreneurial university availability at the PPU attributed to work experience and position?

\section{Literature Review And Policy Environment}

Etzkowitz (2003) defines the Enterpruinal University (EU) as the natural incubator that provides the faculty and students with a supportive structure to start new intellectual and commercial projects by creating multiple knowledge, scientific fields, and new complementary industrial sectors. Salem (2014) defined the EU concept as a university that provides environments, cultures, practices, and opportunities to foster entrepreneurship among workers, students, and alumni. The University possesses a wide range of mechanisms to promote entrepreneurship. These mechanisms include entrepreneurship courses, organizational restructuring of the University to allow effective promotion of entrepreneurship among students and the faculty, and a comprehensive internal system for the marketing of knowledge produced. This would also include technology transfer offices and research budgets to meet public and private sector requirements, consulting services, which contribute to creating companies for students. (Jacob, Laundqvist, \& Hellsmark, 2003). It is also known as the University that actively identifies and invests opportunities in research and education to develop itself, transferring knowledge to the surrounding community through the interaction between the University, government, and industry. Hence, these steps will meet the knowledge economy's requirements, strengthen the national economy, and keep pace with global developments (Sam \& van der Sijde, 2014).

Abu Labhan (2018) defines the EU as the University that adopts a comprehensive approach to achieve economic and social development at the national and regional levels by preparing a generation of entrepreneurs with work opportunities. This achievement requires an entrepreneurial spirit that encourages the investment of opportunities and ideas in various fields, which is conducted by translating such opportunities into the business through managing and investing resources in cooperation with the various internal and external stakeholders. Fernández, Arruti, and Sáenz (2018) say that: "Most universities perform entrepreneurial activities, but not all of them can be defined as entrepreneurial universities." The EU is the University that influences economic development and economic growth through its entrepreneurial activities that depend on technological development and is concerned and interested in research, the development of research abilities, and the transformation of technology (Zhou\& Peng, 2008). Guerrero \& Urbano (2010) defined the EU as a university that meets the community and market needs by developing the organizational potentials, innovation, creativity, and creating opportunities while considering risks that may occur. Al-Hajjar (2018) defined it as the University, which provides innovative programs and services in teaching, scientific research, and community service. It occupies a unique place among universities and can absorb or predict risks and invest in them as 
positive opportunities. It is always a leader in every progress and development felt by workers, beneficiaries, and society. Abdel Wahab (2018) defined the EU as the University that has succeeded through practical paths in shifting from the traditional university-style related to education and research to another style that gives non-traditional attention to integrating university jobs from education and scientific research and community service to play a significant role in supporting the system of innovation and entrepreneurship and contributing to economic and social development and providing the requirements of the knowledge economy By investing in innovative knowledge.

According to Isenberg (2011), an entrepreneurial ecosystem consists of elements grouped into six domains: conducive culture, facilitating policies and leadership, availability of dedicated finance, relevant human capital, venture-friendly markets for products, and a broad institutional set and infrastructural supports. Rice, Fetters \& Greene (2014) indicated that the University should have a university-based Entrepreneurship ecosystem to be considered an entrepreneurial one. Nicotra et al. (2018) defined the entrepreneurial ecosystem as the combination of social, political, economic, and cultural elements in a region that supports the development and growth of innovative startups and encourages new entrepreneurs and other actors to take the risk of starting, funding, and in other ways helping high-risk businesses.

From the researchers' point of view, as aforesaid, the entrepreneurial University can be defined as the University that works with unremitting steps towards being distinguished in all its strategic, organizational, educational, humanities, environmental, and financial levels. Consequently, it can also include the university curriculums, scientific research, and entrepreneurial education to achieve projects and applied research to address the local community's problems. Besides, the University's role expands to providing knowledge and making and transferring the knowledge locally and internationally, and creating jobs for graduates rather than just employment.

\subsection{Entrepreneurial university indicators}

The Organization for Economic Co-operation and Development (OECD) has designed a framework for the universities concerned with strategic planning and decision-making that seek advice, guidance, and inspiration for the effective management of higher education institutions. It is designed for universities interested in self-assessment to keep pace with universities' development and reach the required levels. The OECD (2012) pointed out that the framework factors are dedicated as follows:

- Leadership and governance;

- Organizational capacity, people, and incentives;

- Entrepreneurship development in teaching and learning;

- Pathways for entrepreneurs; and

- University - business/external relationships for knowledge exchange. 
On the other hand, Abu labhan (2018) suggested a proposed model for strengthening the implementation of entrepreneurial universities criteria which consist of: leadership and governance, organizational ability, entrepreneurial teaching and learning, supporting entrepreneurs, sharing and exchange knowledge, internationalization, institutional impact measurement. Whereas, Al-Shammari (2010) indicated that there are five requirements for the transformation into an entrepreneurial university as shown below:

- Transforming the University's role from a focus on employment to focusing on job creation;

- True partnership with stakeholders from public and private sectors and graduates

- Technology and knowledge transfer;

- Education-based on creativity and innovation; and

- Leadership capable of providing material and moral capabilities to entrepreneurs.

In the same context, other studies dealt with the subject of an entrepreneurial university requirement, such as (Al-Sirr, 2017) recommended the necessity of concerning the culture of entrepreneurship at Palestinian universities in the Gaza strip, besides, to provide an entrepreneurial environment that supports innovation, creativity, excellence, and achievements. Whereas the study (Haboush,2017) also recommended developing special courses for entrepreneurship, developing courses and curricula for entrepreneurship, and the need for the University to pay attention to scientific research and link it with the labor market.

Based on the previous entrepreneurial university models for both OECD (2012) and Abu labhan (2018), taking into account the findings and recommendations for other related studies such as Al-Sirr (2017), Haboush (2017), and Al-Shammari (2010). The requirements for achieving the entrepreneurial University that this study derived are curriculum, which meets labor market needs, entrepreneurial education, University's policies and regulations, university leadership, the culture of entrepreneurship, scientific researches and innovations, community relations and partnerships, university environment, academic exchange, and university internationalization. This study, therefore, adopts the entrepreneurial framework of the OECD (2012) and Abu labhan (2018) model as they agree about universities' entrepreneurship requirements.

\subsection{The PPU's achievements of entrepreneurial activities}

Despite the challenges related to the occupation procedures that still put obstacles for achieving constructive communication, the PPU still opens horizons of cooperation with many international institutions, whether in Europe or America. Simultaneously, many researchers and academics participated in many international academic and research exchange programs and cooperation with prestigious research centers and universities. To enhance the competitiveness of the PPU, it focused on the student exchange programs as possible. On the other hand, the University continues to build on its accumulated achievements by serving its society, which distinguished it from similar national institutions. Moreover, it continues to enhance the service departments' efficiency and the excellence of the services they provide. In addition to the endeavor to achieve integration between the various axes that the University is working 
on, and achieve its strategy towards enhancing the competitiveness of the University. (Palestine Polytechnic University site, 2017)

It is worth saying that despite the lack of national financial support for scientific research activities, researchers have managed to win support for their research projects from international and regional funds. In the year 2019, the value of the funded research projects exceeded one million dollars, which was accompanied by an increase in scientific publishing for researchers and specialized research centers. (Palestine Polytechnic University site, 2017).

\section{Methodology}

The study undertakes a quantitative-exploratory approach using statistical techniques of t-test, ANOVA, Kruskal-Wallis test, and Pairwise comparisons supported by qualitative discussions. It is also considered an exploratory methodology that investigates entrepreneurship's phenomenon at the University to explore the requirements to transform the University into an entrepreneurial. After reviewing the literature review from previous studies, a questionnaire was designed to collect the data, which was processed and analyzed. Furthermore, an interview was conducted to explain some facts about the reality of entrepreneurship at the PPU.

\subsection{Population, sampling, and data collection}

The target population of this study consists of senior and middle management employees at the Palestine Polytechnic University, whose total number was (38). The categories of the employees who participated in the study are the President, Vice presidents, Deans, Heads of Academic Departments, Directors of relevant Administrative Departments, Managers of relevant Centers. As the study sample has undertaken the whole study population, table (1) below describes the study population in detail.

The primary data was collected through a questionnaire and an interview. The questionnaire was developed based on the literature review and previous studies that were then presented to arbitrators, who offered their remarks and suggestions that helped the researchers better develop the questionnaire to serve the purposes for which it was designed. In contrast, the secondary sources relied on previous studies and other literature, such as books, thesis, articles, periodicals, and online articles related to universities' transformation towards entrepreneurship.

At the time of distributing the questionnaires, in-person interviews were conducted with employees in the senior and middle management at the University to enhance the results' discussion. All of the 38 distributed questionnaires were received back from the respondents, and all of them were valid for the statistical analysis. Another interview was conducted with the PPU president to ensure no inconsistencies in the questionnaire's answers.

\subsection{Study operational variables}


The Independent Variables are the Curricula, entrepreneurial education, policies and systems, university leadership, the culture of entrepreneurship, scientific research and innovation, community relations and partnerships, university environment, academic exchange, and university internationalization. The Moderate Variables are years of experience and current position. The Dependent variable is the Entrepreneurial University, characterized by creativity, innovation, good reputation, and startups established through its innovative graduated students.

\subsection{Validity of study tool}

Concerning the Context validity, an academic supervisor and specialists in the study field have checked the validity of the questionnaire. They stated that the questionnaire is valid and appropriate to achieve the purpose of the study. While the Structural validity shows a high internal consistency between paragraphs in the questionnaire, as shown in table (2) below, the instrument is suitable for performing the intended measurement.

\section{Results}

This important section focusses on the study findings with discussions and interpretations. However, table (3) below describes the means and standard deviations, sorted in descending order according to the mean values, of the total degrees of the themes of entrepreneurship at PPU.

The results showed that the levels of the curriculum and the labor market, community relations and partnerships, the academic exchange, the culture of entrepreneurship, and the entrepreneurial education themes are high However, the levels of themes regarding the university's internationalization, regulations, and policies, scientific research and innovations, leadership, and the environment are moderate. This can be seen from the table above.

By answering the question regarding the reality of entrepreneurship at PPU from the senior and middle management perspective, the researcher believes that the highest mean emerged in the curriculum and labor market theme which was (3.8). This result needs PPU to recognize that this theme has the greatest importance in the university's priorities to be an entrepreneurial university. Therefore, the university needs to pay attention to developing curricula that are compatible with the labor market needs due to its significant impact on the university's entrepreneurship and development. The analysis showed that the university pays specific attention to its relations and partnership with the community segments. As a result, these relations affect positively the university's reputation and help to increase the university's finance through constructing many campuses and a new building that benefits the university, students, and staff.

As for the entrepreneurial education theme; the researcher believes that it has high attention at PPU because the university strives to do the best possible in education to maintain certain objectives. Moreover, most of the lecturers attempt to use modern tools in the teaching process, and there is a good concern about the flipped teaching and eLearning. On the other hand, The Center for Excellence in 
Teaching and Learning (CETL) at PPU conducts continuous training and workshops in the teaching and learning process at PPU. This shows how PPU pays great attention to entrepreneurial education.

From the researcher's view; the theme of the university's policies and regulations has a moderate level because the concept of entrepreneurship is a modern one, and the university does not possess a model towards the transformation into an entrepreneurial university. Consequently, this study will assist in constructing an appropriate model that suits the Palestinian situations and universities. However, the results showed that the lowest percentage was for the theme of university's environment that scored a mean of $(3,1)$. This explains the approval of the most of workers in the middle and senior management that this theme is less important in the university because of physical constraints that face the university due to the lack of financial support from the Palestinian government. The researcher illustrates this in more detail at the end of this chapter, more specifically in the analysis of the interview conducted with the president of the PPU.

Table (4) below is a ranking question that shows the elements ranking for a transition into an entrepreneurial university in order of importance, ranking the most important 1 , the next 2 , and so on. The results show that the most important requirements necessary to transform PPU into an entrepreneurial university are: university's leadership and entrepreneurship culture with relative frequencies of: 0.32 and 0.29 respectively. Whereas the academic exchange is the least important requirement with a relative frequency of: 0.03 from the perspective of the senior and middle management at PPU.

Figure (1) illustrates the priorities of the university requirements that are required for the transformation of PPU into an entrepreneurial university, which is based on the results of the third question of this study, and form the perspective of senior and middle management. It shows that a university's leadership is the most important requirement for the university, while the academic exchange is the least important one.

Figure (2) shows the pairwise comparison between respondents' perspectives towards university's leadership theme according to the current job shows that there is a significant difference between the head of the academic department and vice president, in addition to the difference between the head of the academic department and the university president, with P-values: .010, .041 respectively, which is less than the significance level $(\alpha=.05)$.

Figure (3) shows the pairwise comparison between respondents' perspectives towards university's environment theme, according to the current job, shows that there is a significant difference between the vice president and [head of academic department, center director and deans], with P-values: .009, .016, .048 respectively, which is less than the significance level $(a=.05)$.

Figure (4) shows the pairwise comparison between respondents' perspectives towards university's internationalization theme, according to the current job, shows that there is a significant difference between the vice president and [center director and head of academic department], with P-values : ).008, .009 ( respectively, which is less than the significance level $(a=.05)$. 
According to the previous results, it can be noticed that PPU has the willingness to be an entrepreneurial university. It attempts, as much as possible, to reach this trend despite the restriction of the financial item. Additionally, it tries to do entrepreneurial activities and concerns on the aspects that can raise its development and reputation by continuing in its vision of entrepreneurship in the light of the existing financial problem. The researcher adopts the results and concludes that the university should continue with the entrepreneurship concept gradually depending on the reality of the actual situation of PPU as appeared from the responses of the senior and middle management. It is worth mentioning that PPU is a Palestinian university, which has a special situation due to the Israeli occupation.

In summary of all of the abovementioned survey and interview findings, figure (5) below shows the steps required for the transition of PPU into an entrepreneurial university, organized in ascending order and based on the researcher's perspective.

However, the results of the One-Way Analysis of Variance (ANOVA) and Kruskal-Wallis test regarding the differences show that there is a significant difference between respondents' evaluation of the curriculum and the labor market criteria, with P-value:.000 which is less than the significance level $(a=.05)$. Also, the means were not equal for (1) respondents' evaluation of the entrepreneurial education criteria; (2) respondents' evaluations regarding the university's policies and regulation criteria; (3) the respondent's evaluation of the culture of entrepreneurship criteria; (4) respondents' evaluation of the scientific research and innovations criteria; (5) respondents' evaluation of the community's relations and partnerships criteria; (6) respondents' evaluation of the university's environmental criteria; and (7) respondents' evaluation of the university's internationalization criteria.

In contrast, the results of ANOVA of the differences show that there are no significant differences between respondents' evaluation of the university's leadership criteria, with P-value: .182, which is larger than the significance level $(a=.05)$. Also, the means were not equal for the respondent's evaluation of the university's leadership criteria, and between respondents' evaluation of the academic exchange criteria.

In light of the study results shown above, the university should go step by step in its entrepreneurship policy. It should start from the leadership by disseminating and spreading awareness about the culture of entrepreneurship throughout the university's staff and students. In the next step, the university should focus on entrepreneurial education since it is a very important aspect for graduates who have innovative ideas that enable them to start their own startups. The university policies should be taken into account since they are the systematic way to achieve the goal of entrepreneurship, which is followed by the scientific research theme because the innovations resulted from the research are the basic point for any university to be a leading one. Moreover, the university's environment would be the next step because it influences the achievements and efforts of students and staff. The university should focus more on its environment, which is considered as the eighth step, and since this environment is the mirror to the community, and needs to keep in pace with other leading universities externally. The ninth step would go for the university's relations and partnership, which are important to increase the cooperation agreements between the university and community, and can develop w the curricula and majors to suit the needs of 
the community and labor market. Academic exchange, which is important to increase experiences between the university and leading universities abroad would be the last step for the transition of the university into an entrepreneurial one.

On the other hand, the questionnaire's findings show that there are differences between the responses of the senior and middle management, which means the closer the current work is to the senior management, the more the answers will be different, as the employees in the senior management differ their point of views on the reality of entrepreneurship in the University, given their broader authorities in leadership, decision-making, developing plans and the University's vision, in addition to the external and international dealings. This explains the different responses in the themes of university leadership, university environment, and internationalization. It also reveals that the PPU lacks a systematic methodology to align curricula with the labor market's needs. This is due to the Palestinian industry limited to local industries, with low competitiveness in this issue as the Palestinian situation is constantly changing.

The findings also show that the PPU faces' financial crisis had caused a decrease in the percentage of financial incentives given to employees in exchange for the pioneering results obtained. These incentives are limited to the ones received through funded projects, where most of these projects are subject to the donors' terms and not to PPU needs. In contrast, the PPU's scientific researches are in a step towards progress despite the existing obstacles. Furthermore, it was shown that linking research results with the labor market's needs by creating innovative companies affiliated with the PPU would require a complete system to follow the practical research, a general policy to encourage scientific research, and approval from the High Authority in Palestine.

One of the main findings shows that PPU has a limited role in converting theoretical research outputs into practical innovations. This is because scientific research needs to be financed and allocated a specific budget and risky. After all, the results may not achieve the required goal. On the other hand, the contribution of the community's relations and partnerships in financing PPU projects was limited to finance the infrastructure and does not go for the University to improve its environment. However, the University is trying to pursue its vision of entrepreneurship within the existing context despite the financial hardship.

Regarding the PPU's scholarships offered for faculty members to study at leading universities worldwide, it was found that there is no scholarship system in the University because this issue is related to the financial aspect in addition to lack of governmental support for this issue.

\section{Conclusions}

As a final result, and from the researchers' point of view, entrepreneurship is considered an integrated process consisting of a group of elements. The absence of any of these elements may negatively affect the overall process's performance. Depending on this point, the researchers propose a model for PPU transition towards an entrepreneurial university which is the overall objective of this study. The below 
Figure (6) presents a model for the entrepreneurial University that the researchers propose. Furthermore, the conditions are linked to each other, taking into consideration that the absence of any of these requirements will cause a disorder in the achievement of PPU's entrepreneurship vision as required. The researchers added a requirement, which is (funding resources) that may accelerate the University's entrepreneurship success as needed. This requirement contributes to increasing the capability of the University for facing its financial problems that may touch other requirements in the proposed model.

The study confirms the definition of the entrepreneurial University, which was derived from the study findings and the theoretical framework, which is as "The University that works with unremitting steps towards being distinguished in all its strategic, organizational, educational, humanities, environmental, and financial levels. This can also include the university curriculums, scientific research, and entrepreneurial education, for the aim of achieving projects and applied research, that are supposed to address the problems of the local community. Besides, the University's role expands to not only providing knowledge but also into making and transferring the knowledge locally and internationally, in addition to focusing on creating jobs for graduates rather than just employment".

\subsection{Policy implications}

The following table (5) shows in detail the process that PPU has to do to develop entrepreneurship concerning each component taking into account the funding resource component which accelerates the process of achieving entrepreneurship at PPU.

\subsection{Further Research:}

This study focused on studying the reality of entrepreneurship at Palestine Polytechnic University from the perspective of senior and middle management, it is necessary to conduct other studies related to this subject that measure the impact of achieving entrepreneurship requirements at PPU. It is also important to conduct another study from the students', graduates', and teachers' perspectives. Other studies are required to know the extent of achieving entrepreneurship requirements in Palestinian universities. In addition to the role of the entrepreneurial University in achieving competitiveness among Palestinian universities. In the same context, it is important to explore the purpose of the funding resources to attain entrepreneurship at Palestinian universities. Furthermore, many studies are required in Palestine to detect the role of every component of the entrepreneurial University in achieving entrepreneurship at Palestinian Universities.

\section{Abbreviations}

CETL: Excellence in Teaching and Learning; ANOVA: One-Way Analysis of Variance; and PPU: Palestine Polytechnic University.

\section{Declarations}


Data and materials availability: The Data and materials used in this paper were primary data collected through a questionnaire and an interview were administrated to the target population.

Competing interests: The authors declare that they have no conflict of interest or competing interests.

\section{Funding: N/A.}

Contributions: The co-authors made a significant contribution and agreed with the contents of this paper.

\section{Acknowledgment}

In preparation for this paper, I had to take the help of some respected professors and researchers, who deserve my deepest gratitude. As the completion of this paper gave me much pleasure, we would like to express my appreciation for all those who have directly and indirectly helped us in preparing this research paper.

\section{References}

1. Abdel Wahab, E. (2018). : "Pathways of transformation in Egyptian university education institutions towards an entrepreneurial university formula, a forward-looking study", research published in the Journal of the Faculty of Education, Kafr El-Sheikh University, No. (90), Vol. (2). [In Arabic]

2. Abu Labhan, M. (2018). "Towards an entrepreneurial university in Egypt: a proposed vision", Faculty of Education Journal. Egypt[In Arabic]: Tanta University, College of Education

3. Al-Hajjar, R. (2018). "A Proposed Strategy to Transform Alaqsa University Palestine. In To Entrepreneurial University", Educational Journal. Kuwait University - Scientific Publishing Council[In Arabic]

4. Al-Shammari, A. (2010). : "The five requirements for an Entrepreneurial University", Article.[In Arabic]. [online], Last visited: $11 / 6 / 2020$, retrieved from the website: (https://www.aleqt.com/2010/02/14/article_349311.html)

5. Al-Sirr, D. (2017). : "The availability of education requirements in leading the Palestinian universities in the Gaza Strip and ways of strengthening them", M.A. thesis, education college, Islamic University, Gaza, Palestine. [In Arabic]

6. Etzkowitz, H. (2003). Research groups as Quasi Firms".. The invention of the Entrepreneurial University, Research Policy

7. Etzkowitz, H. (2006). : "The Entrepreneurial University and the Triple-Helix as A Development Paradigm", Ethiopia Triple Helix Conference, Addis Ababa.

8. Fernández, D., Arruti, A., \& Sáenz, N. (2018). "The entrepreneurial university: A selection of good practices". Spain: Journal of Entrepreneurship Education, University of Deusto, Mondragon University

9. Guerrero, D., Urbano, A., \& Fayolle, M. (2016). "Entrepreneurial universities: Emerging models in the new social and economic landscape. " Small Business Economics 
10. Haboush, I., \& Thesis, M. A. "The Role that Palestinian Universities in Gaza Governorates Play in Reinforcing and Developing Their Students Entrepreneurship Skills", ed(2017). ucation Faculty, Islamic University, Gaza, Palestine. [In Arabic]

11. Interview (2019). : In-person with senior and middle management at PPU.

12. Isenberg, D. (2011). : "How to Foment an Entrepreneurial Revolution", the Babson Entrepreneurship Ecosystem Project, Babson Global, Babson college, United States

13. Jacob, M., Lundqvist, M., \& Hellsmark, H. (2003). : "Entrepreneurial Transformation in the Swedish University system: The case of Chalmers University of Technology", Research Policy.

14. Nicotra, M. et, al(2018). : "The causal relation between entrepreneurial ecosystem and productive entrepreneurship: a measurement framework", Article,The Journal of Technology Transfer, Vol. (43), Issue 3.

15. OECD. (2012). "A Guiding Framework for Entrepreneurial Universities". European commission

16. Palestine Polytechnic University site Palestine. [Online], Last visited on: $31 / 5 / 2020$, retrieved from the website: (https://www.ppu.edu/)

17. Rice, M., Fetters, M., \& Greene, P. (2014). " University-based entrepreneurship ecosystems: A global study of six educational institutions", Article. International Journal of Entrepreneurship and Innovation Management

18. Salem, M. A. (2014). : "Higher education as pathway to entrepreneurship".International business and economic research Journal, Vol. (13), No. (2). [In Arabic]

19. Sam, C., \& van der Sijde, P. (2014). : "Understanding the concept of the entrepreneurial university from the perspective of higher education models", Higher Education.

20. Zhou, C., \& Peng, X. (2008). The entrepreneurial university in China: nonlinear paths. Science and Public Policy

\section{Tables}

Table 1. List of targeted departments and centers of the study population 


\section{No. Category}

1.

$$
\text { Presidents }
$$

Vice Presidents

1.

1.

1.

1.

1.

1.

1.

1.

1.

1.

1.

1.

1.
Deans
C Deans

.

.

.

.

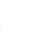

.

1.

1.

Heads of Academic Departments Mechanical Engineering Department

1.

1.

1.

\section{Category Name}

President

Academic Affairs

Administrative Affairs

Planning Affairs

Community Services

Registration and Admission

Scientific Research

Students Affairs

Faculty of Engineering

Faculty of IT and Computer Engineering

Faculty of Applied Science

Faculty of Administrative Science and Informatics

Faculty of Applied Professions

Electrical Engineering Department

Civil and Architectural Engineering Department

Mathematics Department

Computer Engineering Department

Computer Science and IT Department 
1.

1.

1.

1.

1.

1.

1.

1.

1. Departments

1.

1.

1.

Managers of Centers

1.

1.

1.

1.

1.

1.

1.
Chemistry Department

Administrative Science Department

Information System and Multimedia Department

Civil and Architectural Engineering Professions Department

Mechanical and Electrical Engineering Professions Department

Administrative Sciences Department

Computer and Information Technology Department

Banking and Finance Department

Technical Consultancy Department

Quality Assurance Department

Public Relation Department

Language and Translation center

Computer Center

Biotechnology Research Center

Excellence in teaching and learning Center

Continuous Education Center

Stone and Marble Center

Industrial Synergy Center

Occupational Safety and Health Center 
Table 2. Pearson Correlations between questionnaire's sections and total degree

\begin{tabular}{|lllr|}
\hline Section's Number & Section's Title & Pearson correlation & Sig. \\
\hline 1 & The Curriculum and the Labor Market & $.550^{\star \star}$ & .002 \\
\hline 2 & Entrepreneurial Education & $.635^{\star \star}$ & .000 \\
\hline 3 & University Regulations and Polices & $.909^{\star \star}$ & .000 \\
\hline 4 & University Leadership & $.803^{\star \star}$ & .000 \\
\hline 5 & The Culture of Entrepreneurship & $.769^{\star \star}$ & .000 \\
\hline 6 & Scientific Researches and Innovations & $.916^{\star \star}$ & .000 \\
\hline 7 & Community Relations and Partnerships & $.808^{\star \star}$ & .000 \\
\hline 9 & University Environment & $.821^{\star \star}$ & .000 \\
\hline 10 & The Academic Exchange & $.797^{\star \star}$ & .000 \\
\hline
\end{tabular}

Table 3. Means and Std. deviations of the reality of entrepreneurship at PPU

\begin{tabular}{|lllll|}
\hline Section Number & Tittle & Mean & Level & Std. Deviation \\
\hline 1 & Curriculum and the Labor Market & 3.8682 & High & .52700 \\
\hline 3 & Community Relations and Partnerships & 3.8600 & High & .65925 \\
\hline 4 & Academic Exchange & 3.7095 & High & .72532 \\
\hline 5 & The Culture of Entrepreneurship & 3.6639 & High & .57329 \\
\hline 6 & Entrepreneurial Education & 3.6160 & High & .61301 \\
\hline 7 & The University's Internationalization & 3.4282 & High & .63861 \\
\hline 8 & University's Polices and Regulations & 3.3684 & Moderate & .83552 \\
\hline 9 & Scientific Researches and Innovations & 3.3031 & Moderate & .64427 \\
\hline 10 & University's Leadership & 3.2939 & Moderate & .85656 \\
\hline
\end{tabular}


Table 4. Ranking question (Relativie frequencies)

\begin{tabular}{|lll|}
\hline No. & Elements for a transition into an entrepreneurial university & Relative frequencies \\
\hline 1. & University's leadership & 0.32 \\
\hline 2. & Entrepreneurship culture & 0.29 \\
\hline 3. & Entrepreneurial education & 0.16 \\
\hline 4. & University's policies and regulations. & 0.13 \\
\hline 5. & An appropriate curriculum that meets the labor market's needs. & 0.11 \\
\hline 6. & Scientific research and innovations. & 0.08 \\
\hline 7. & University's environment. & 0.05 \\
\hline 8. & University's internationalization & 0.05 \\
\hline 9. & Community's relations and partnerships & 0.03 \\
\hline 10. & Academic exchange. & 0.03 \\
\hline
\end{tabular}

Table 5. The process to develop entrepreneurship at PPU 


\section{Funding \\ Resource \\ (Accelerating \\ PPU model components \\ Process}

element)

University leadership
Culture of entrepreneurship
- Responding to the changes that occur in the local environment.

- Implementing a policy of decentralization.

- Integrate the performance of its various faculties.

- Management according to its objectives,

- Diversifies funding sources to maintain independence.
- Train employees on the application of entrepreneurial ideas in business.

- Encourages its employees to participate in external developmental programs.

- Engaging the Students' Union Council in the implementation of its entrepreneurial ideas.

\section{Entrepreneurial education}

- Policies that encourage teachers to use a special case study

- Policies that encourage teachers to use (critical thinking).

- Policies that encourage teacher's simulation strategy.

- Analyze students' strengths and weaknesses points.

\section{University's policies} and regulations
- Granting moral incentives for the entrepreneurial results

- Financing entrepreneurial projects for students.

- Regulations for entrepreneurial activities.

- Bank of entrepreneurial ideas resulting from research.

- Granting financial incentives for entrepreneurial results.

\section{Curriculum and labor market}

- Developing curricula according to the labor market.

- Develop curricula to keep pace with scientific development.

- Continuously update curriculum plans.

- Achieving interdisciplinary objectives.

- Raising students' higher thinking levels.

- Compatibility between outputs and labor market needs.

- Students' assessment of consistent with the courses' outcomes.

- Systematic methodology in studying labor market needs. 
innovations

Entrepreneurial environment

- Publishing research in scientific journals.

- Allocating a specific budget for research.

- Activate the role of the innovation center and technology transfer resulting from applied research.

- Researches associated with the needs of the labor market.

- Provides necessary capabilities for the work of pilot research projects.

- The increasing number of patents associated with research results.

- Transfer the outputs of applied research (innovations) to the labor market.

- Creating innovative companies.

- Equipment's for various teaching aids.

- Required medical care for students.

- Staff with a suitable environment

- Special services for students with special needs.

- Multi-purpose halls for students' activities.

- Yards to suit the number of students.

- Large green areas.

\section{Community relations} and partnership
- Increasing relations and community partnerships to its financial returns.

- Increasing community partnerships to enrich academic curricula.

- Increasing relations and community partnerships to raise finance.

- Increasing relations and community partnerships to increasing the number of practical researches which correspond to the needs of the labor market.

\section{Academic exchange}

- Guidance and counseling for students who are offered a scholarship.

- Increasing academic exchange opportunities for both students and teachers.

\section{Internationalization}

- World-class professional development programs for faculty.

- Sending the academics to world-leading universities.

- Hosts international visiting teachers.

- Attracting internationally renowned faculty to work. 


\section{Figures}

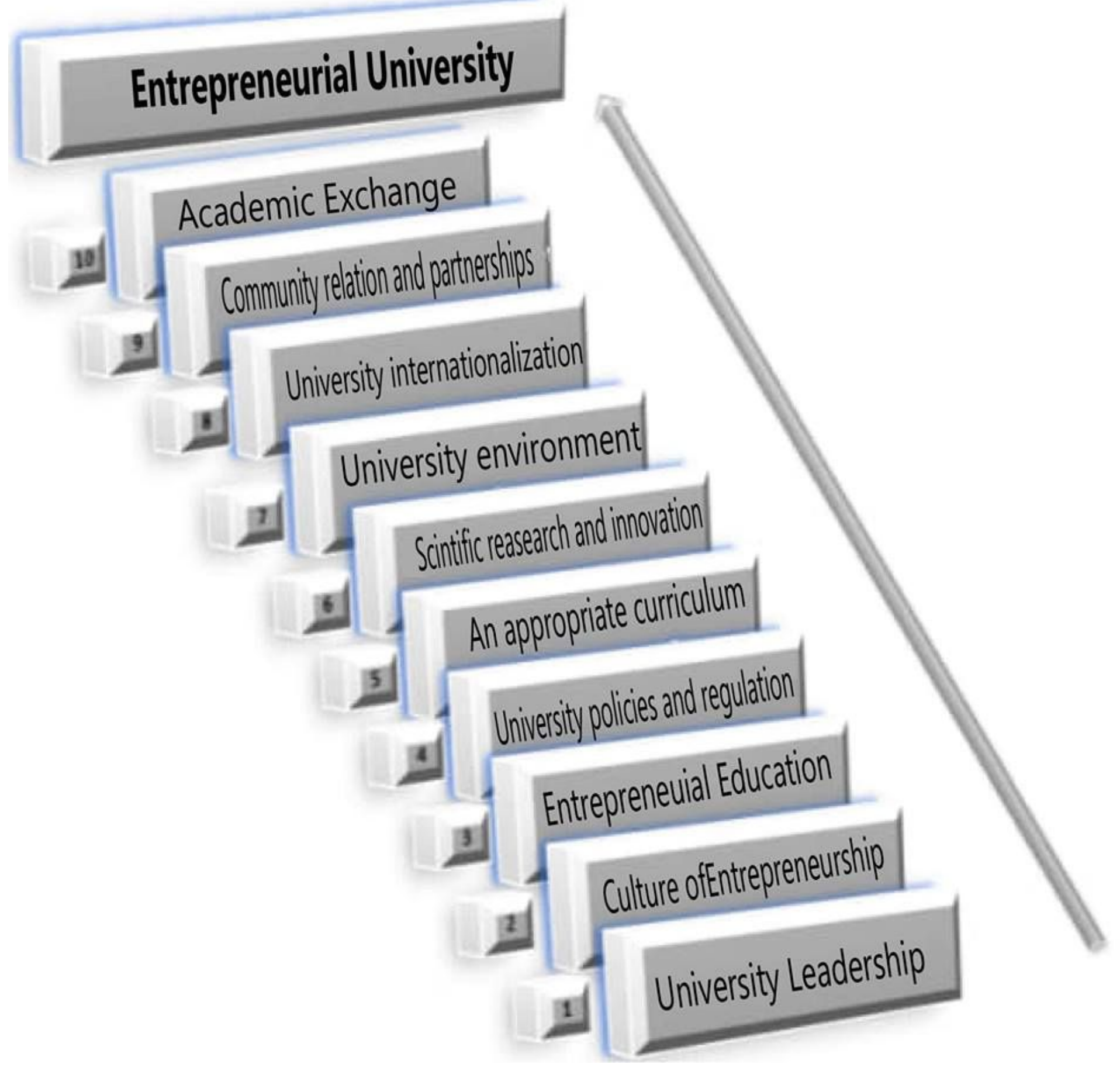

Figure 1

Priorities of the university's requirements required for the transition into an entrepreneurial university 


\section{Pairwise Comparisons of current job}

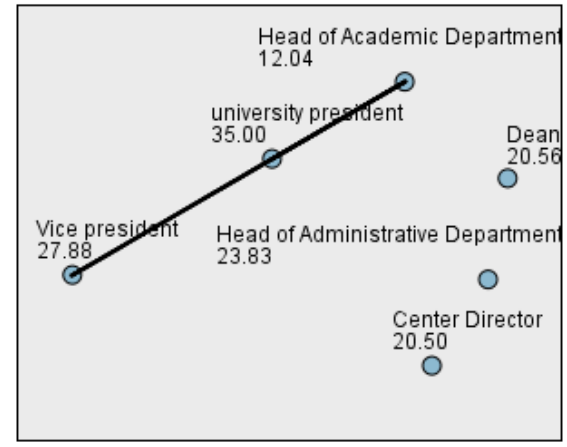

Each node shows the sample average rank of current job.

\begin{tabular}{|c|c|c|c|c|c|}
\hline Sample1-Sample2 & $\begin{array}{c}\text { Test } \\
\text { Statistic }\end{array}$ & $\begin{array}{l}\text { Std. } \\
\text { Error }\end{array}$ & $\begin{array}{l}\text { Std. Test } \\
\text { Statistic }\end{array}$ & Sig. & Adj.Sig. \\
\hline $\begin{array}{l}\text { Head of Academic Department- } \\
\text { Center Director }\end{array}$ & $8.462-$ & 4.855 & $1.743-$ & .081 & 1.000 \\
\hline $\begin{array}{l}\text { Head of Academic Department- } \\
\text { Dean }\end{array}$ & 8.524 & 4.855 & 1.756 & .079 & 1.000 \\
\hline $\begin{array}{l}\text { Head of Academic Department- } \\
\text { Head of Administrative } \\
\text { Department }\end{array}$ & $11.795-$ & 6.920 & $1.704-$ & .088 & 1.000 \\
\hline $\begin{array}{l}\text { Head of Academic Department- } \\
\text { Vice president }\end{array}$ & 15.837 & 6.177 & 2.564 & .010 & .155 \\
\hline $\begin{array}{l}\text { Head of Academic Department- } \\
\text { university president }\end{array}$ & 22.962 & 11.212 & 2.048 & .041 & .608 \\
\hline Center Director-Dean & .062 & 5.402 & .012 & .991 & 1.000 \\
\hline $\begin{array}{l}\text { Center Director-Head of } \\
\text { Administrative Department }\end{array}$ & 3.333 & 7.314 & .456 & .649 & 1.000 \\
\hline Center Director-Vice president & 7.375 & 6.616 & 1.115 & .265 & 1.000 \\
\hline $\begin{array}{l}\text { Center Director-university } \\
\text { president }\end{array}$ & 14.500 & 11.459 & 1.265 & .206 & 1.000 \\
\hline $\begin{array}{l}\text { Dean-Head of Administrative } \\
\text { Department }\end{array}$ & 3.271- & 7.314 & $.447-$ & .655 & 1.000 \\
\hline Dean-Vice president & 7.312 & 6.616 & 1.105 & .269 & 1.000 \\
\hline Dean-university president & 14.438 & 11.459 & 1.260 & .208 & 1.000 \\
\hline $\begin{array}{l}\text { Head of Administrative } \\
\text { Department-Vice president }\end{array}$ & 4.042 & 8.252 & .490 & .624 & 1.000 \\
\hline $\begin{array}{l}\text { Head of Administrative } \\
\text { Department-university president }\end{array}$ & 11.167 & 12.475 & .895 & .371 & 1.000 \\
\hline $\begin{array}{l}\text { Vice president-university } \\
\text { president }\end{array}$ & 7.125 & 12.079 & .590 & .555 & 1.000 \\
\hline
\end{tabular}

Each row tests the null hypothesis that the Sample 1 and Sample 2 distributions are the same.

Asymptotic significances (2-sided tests) are displayed. The significance level is .05

Significance values have been adjusted by the Bonferroni correction for multiple tests.

\section{Figure 2}

Pairwise comparisons towards leadership according to the current job 
Pairwise Comparisons of current job

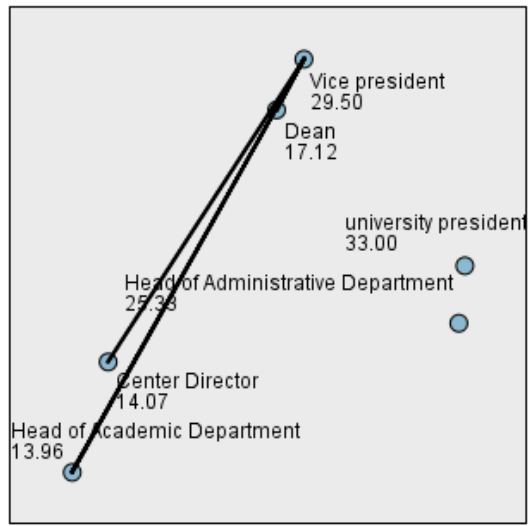

Each node shows the sample average rank of current job.

\begin{tabular}{|c|c|c|c|c|c|}
\hline Sample1-Sample2 & $\begin{array}{c}\text { Test } \\
\text { Statistic }\end{array}$ & $\begin{array}{l}\text { Std. } \\
\text { Error }\end{array}$ & $\begin{array}{l}\text { Std. Test } \\
\text { Statistic }\end{array}$ & Sig. & Adj.Sig. \\
\hline $\begin{array}{l}\text { Head of Academic Department- } \\
\text { Center Director }\end{array}$ & $.113-$ & 4.867 & $.023-$ & .981 & 1.000 \\
\hline $\begin{array}{l}\text { Head of Academic Department- } \\
\text { Dean }\end{array}$ & 3.167 & 4.671 & .678 & .498 & 1.000 \\
\hline $\begin{array}{l}\text { Head of Academic Department- } \\
\text { Head of Administrative } \\
\text { Department }\end{array}$ & $11.375-$ & 6.606 & $1.722-$ & .085 & 1.000 \\
\hline $\begin{array}{l}\text { Head of Academic Department- } \\
\text { Vice president }\end{array}$ & 15.542 & 5.909 & 2.630 & .009 & .128 \\
\hline $\begin{array}{l}\text { Head of Academic Department- } \\
\text { university president }\end{array}$ & 19.042 & 10.652 & 1.788 & .074 & 1.000 \\
\hline Center Director-Dean & 3.054 & 5.297 & .577 & .564 & 1.000 \\
\hline $\begin{array}{l}\text { Center Director-Head of } \\
\text { Administrative Department }\end{array}$ & 11.262 & 7.062 & 1.595 & .111 & 1.000 \\
\hline Center Director-Vice president & 15.429 & 6.415 & 2.405 & .016 & .242 \\
\hline $\begin{array}{l}\text { Center Director-university } \\
\text { president }\end{array}$ & 18.929 & 10.941 & 1.730 & .084 & 1.000 \\
\hline $\begin{array}{l}\text { Dean-Head of Administrative } \\
\text { Department }\end{array}$ & $8.208-$ & 6.928 & $1.185-$ & .236 & 1.000 \\
\hline Dean-Vice president & 12.375 & 6.267 & 1.975 & .048 & .725 \\
\hline Dean-university president & 15.875 & 10.855 & 1.462 & .144 & 1.000 \\
\hline $\begin{array}{l}\text { Head of Administrative } \\
\text { Department-Vice president }\end{array}$ & 4.167 & 7.816 & .533 & .594 & 1.000 \\
\hline $\begin{array}{l}\text { Head of Administrative } \\
\text { Department-university president }\end{array}$ & 7.667 & 11.817 & .649 & .516 & 1.000 \\
\hline $\begin{array}{l}\text { Vice president-university } \\
\text { president }\end{array}$ & 3.500 & 11.442 & .306 & .760 & 1.000 \\
\hline
\end{tabular}

Each row tests the null hypothesis that the Sample 1 and Sample 2 distributions are the

Asymptotic significances (2-sided tests) are displayed. The significance level is .05 .

Significance values have been adjusted by the Bonferroni correction for multiple tests.

\section{Figure 3}

Pairwise comparisons towards environment according to the current job 
Pairwise Comparisons of current job

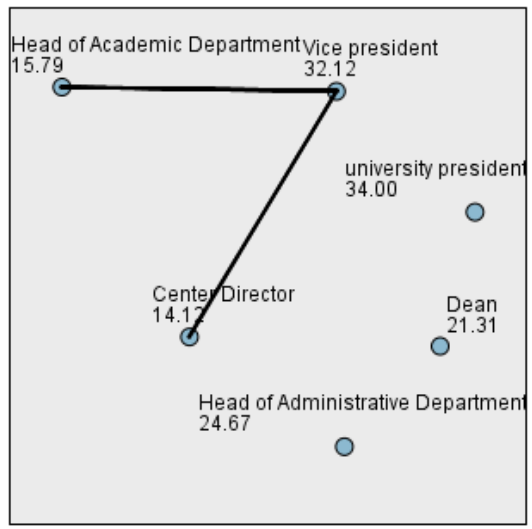

Each node shows the sample average rank of current job.

\begin{tabular}{|c|c|c|c|c|c|}
\hline Sample1-Sample2 & $\begin{array}{l}\text { Test } \\
\text { Statistic }\end{array}$ & $\begin{array}{l}\text { Std. } \\
\text { Error }\end{array}$ & $\begin{array}{l}\text { Std. Test } \\
\text { Statistic }\end{array}$ & Sig. & Adj.Sig. \\
\hline $\begin{array}{l}\text { Center Director-Head of } \\
\text { Academic Department }\end{array}$ & 1.661 & 4.893 & .339 & .734 & 1.000 \\
\hline Center Director-Dean & 7.188 & 5.520 & 1.302 & .193 & 1.000 \\
\hline $\begin{array}{l}\text { Center Director-Head of } \\
\text { Administrative Department }\end{array}$ & 10.542 & 7.474 & 1.411 & .158 & 1.000 \\
\hline Center Director-Vice president & 18.000 & 6.760 & 2.663 & .008 & .116 \\
\hline $\begin{array}{l}\text { Center Director-university } \\
\text { president }\end{array}$ & 19.875 & 11.709 & 1.697 & .090 & 1.000 \\
\hline $\begin{array}{l}\text { Head of Academic Department- } \\
\text { Dean }\end{array}$ & 5.527 & 4.893 & 1.130 & .259 & 1.000 \\
\hline $\begin{array}{l}\text { Head of Academic Department- } \\
\text { Head of Administrative } \\
\text { Department }\end{array}$ & $8.881-$ & 7.023 & $1.265-$ & .206 & 1.000 \\
\hline $\begin{array}{l}\text { Head of Academic Department- } \\
\text { Vice president }\end{array}$ & 16.339 & 6.259 & 2.611 & .009 & .136 \\
\hline $\begin{array}{l}\text { Head of Academic Department- } \\
\text { university president }\end{array}$ & 18.214 & 11.427 & 1.594 & .111 & 1.000 \\
\hline $\begin{array}{l}\text { Dean-Head of Administrative } \\
\text { Department }\end{array}$ & 3.354- & 7.474 & $.449-$ & .654 & 1.000 \\
\hline Dean-Vice president & 10.812 & 6.760 & 1.599 & .110 & 1.000 \\
\hline Dean-university president & 12.688 & 11.709 & 1.084 & .279 & 1.000 \\
\hline $\begin{array}{l}\text { Head of Administrative } \\
\text { Department-Vice president }\end{array}$ & 7.458 & 8.431 & .885 & .376 & 1.000 \\
\hline $\begin{array}{l}\text { Head of Administrative } \\
\text { Department-university president }\end{array}$ & 9.333 & 12.747 & .732 & .464 & 1.000 \\
\hline $\begin{array}{l}\text { Vice president-university } \\
\text { president }\end{array}$ & 1.875 & 12.342 & .152 & .879 & 1.000 \\
\hline
\end{tabular}

Each row tests the null hypothesis that the Sample 1 and Sample 2 distributions are the

Asymptotic significances (2-sided tests) are displayed. The significance level is .05 .

Significance values have been adjusted by the Bonferroni correction for multiple tests.

\section{Figure 4}

Pairwise comparisons towards internationalization according to current job 


\section{Entrepreneurial University}

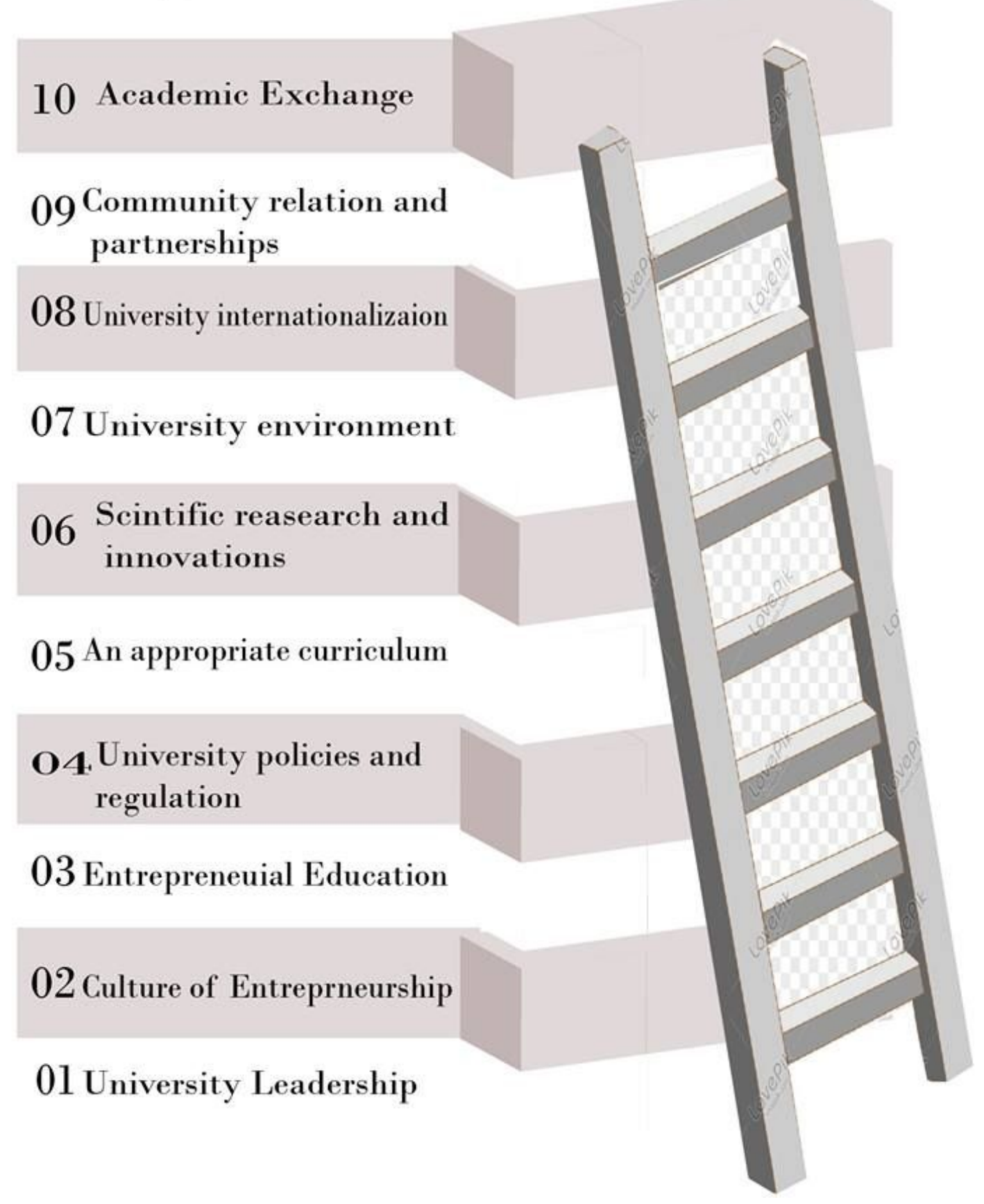

Figure 5

Steps organized in ascending order and required for the transition of PPU into an entrepreneurial university. (Developed by the researcher) 


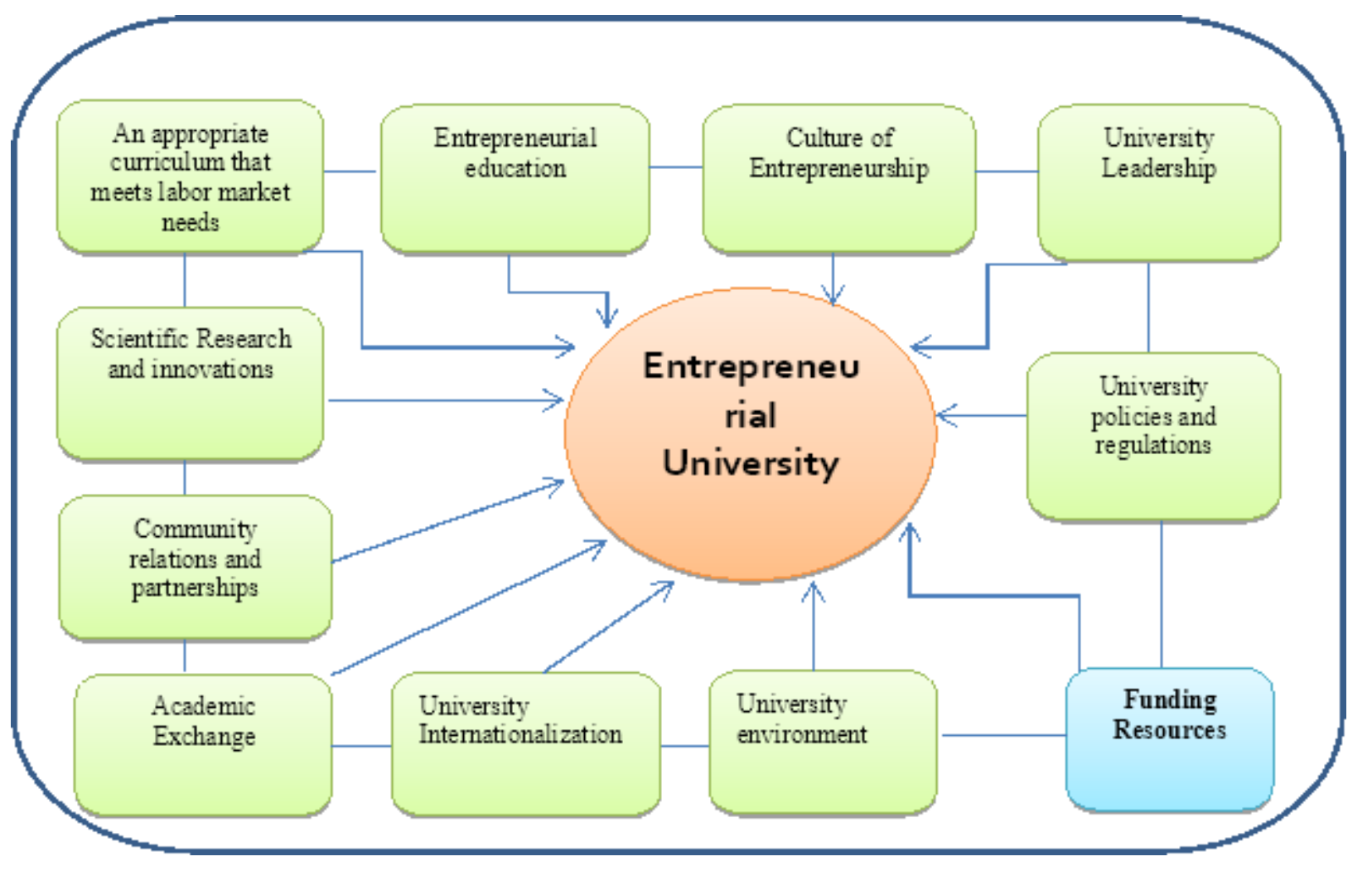

Figure 6

PPU entrepreneurial university model 